\title{
The impact of time management on the success of service organizations
}

\author{
Wiam Wahab Abdel-Hussein \\ Southern Technical University - Technical Institute / Nasiriya \\ WiamAl.yasiri@stu.edu.iq
}

\begin{abstract}
This study aims to identify the effect of time management on the success of service organizations, in order to proceed with the goals that follow this study and find the relationship and influence the dimensions of each of the two variables, which is the first variable time management after the researcher chose the two methods of organization and management of goals, while the second variable was service organizations Which includes organizational performance and creative leadership, as the researcher used the descriptive approach after conducting the field study.
\end{abstract}

Keywords. time management, service goals, organization

\section{Research problem}

The research problem is concerned with attention to knowing the impact of time management, which is one of the most important influences within governmental and nongovernmental institutions and organizations, because time management is one of the foundations through which organizations of all kinds can advance, because time management is one of the requirements upon which the success strategy of those institutions and access is built To administrative creativity within those service institutions that are trying to search for faster and more accurate ways of working to develop the capabilities of organizations and their development, so this problem raises a major question characterized by the following:

- What is the impact of time management on the success of service organizations?

With this question, several questions are branched out, including:

- What are the methods in time to achieve the success of service organizations?

- Is time management important to the success of service organizations?

- Do you address goals on how to use time wisely in order to arrive at good planning for the success of service organizations?

\section{Research hypotheses}

"There is a statistically significant correlation between time management and service goals achievement at the significance level $(0,05)$." 


\section{The importance of research}

The importance of research is to understand and study the two variables according to the impact of time management on the success of service organizations, and what are the most important methods that can meet the aspiration of success for these organizations, since the most important goals that the service organization sets is to reach how to manage the goals of the organization, and then understand How to independently organize time to reach success.

Fourth: Research objectives

- Knowledge of time management methods that meet the aspiration of success in service organizations.

- Knowing how to organize time with the service organization and how to manage its work.

- 3- Understand the goals that the time factor puts in managing the performance of service organizations.

\section{Theoretical}

Time is an important factor which means in its management the rationalization of behavior, and the use of available methods, capabilities and capabilities to achieve the goal required to be accomplished on time, and in terms of motivation, one of the important forces in the system of character building, motivating behavior and directing towards a specific viewpoint (Al-Dhahir, 2013: 9)

Also, the importance of sustenance aims at good organization that can bring the attributes that give importance to time in organizing, according to the tendency to great cooperation between members of the group and a sense of collective responsibility, as well as organizing work across members of the group. (Al-Ajmi, 2010: 305).

Solving many important problems that the organization may encounter listening to all the specialists in it who have a direct relationship with decision-making requires clearing the importance of time in managing the success of service organizations, because time management works to achieve a set of important goals, including: (Al-Sarn, 2018: 124-125)

- Full cooperation between the top management and other executive departments in the organization in order to discuss work problems, discuss negativity and work on continuous development and improvement throughout the organization.

- Detailed study of the topics raised, familiarity with the necessary details of current problems, and listening to different perspectives on all aspects of the topic.

- Take advantage of the expertise of specialists and consultants by listening to the technical point of view of each of them, and the process as well, the more experience, the more optimization of time will be achieved.

- Decision-making unanimously and in a democratic manner that enables those involved in implementation and serious participation in its performance.

- $\quad$ Providing an opportunity to train and prepare young leaders for the future.

- Achieving the collective leadership of the organization so that those responsible for work extend the organization's basic goals.

The relationship indicates that effective time management requires the manager to follow his duties and respect them with high accuracy when dealing with time for the success of the service organization's work, and indicates this through the following: - (Al-Alaq, 2009: $58-62)$ 
1- Planning: It is an administrative function that includes choosing among a number of alternatives the organization's goals, policies, plans and programs necessary to achieve the goals, and it is a decision-making process because it involves choosing between alternatives.

2- Organization: The organization involves creating a deliberate structure for the roles by distinguishing and defining the activities necessary to achieve the goals of the organization and each part of it, grouping these activities and allocating a director to each group of these activities, delegating authority to carry out these activities, and providing coordination of the authority's relationships horizontally and vertically in the organizational structure, and the director at His commencement of the organizational function taking into account the following organizational limitations:

- Work and specialty assessment.

- Presidential hierarchy and career relations process.

- The organizational structure of job design and organizational unit design.

- The scope of supervision and job headquarters.

- Informal organization.

- Centers and roles for each individual.

- The intellectual climate that is related to communications in order to achieve the required coordination effectively.

- Centralization and decentralization.

- Powers, Delegations and Responsibilities.

3- Formation: It means the development of the administrative body, i.e. placing the administrators in the various centers among which the structure of the organization, and then the job necessitates the necessity of specifying the specifications and requirements for every person in charge of a particular position, with the evaluation, selection, and training of candidates.

4- Guidance: The actual initiation of the required operations requires another administrative step, which is to direct individuals and groups through administrative orders, instructions, regulations, communications and leadership oversight of work towards the implementation of operations previously distributed to individuals or groups represented in departments and divisions, and the guidance function It takes place in the light of several considerations, including the naturalness of the individuals or departments assigned to work, the type of work required, as well as the director's assessment and judgment on the course of matters.

5- Oversight: Oversight is the verification that everything is in progress according to the plans laid down, issued instructions and prescribed principles that aim to reveal weaknesses and errors of corrections and prevent them from recurring, which are practiced on everything, as it is a vital component of management that contributes to ensuring proper achievement To work by the efforts of other individuals, and you verify that the work to be performed has been performed satisfactorily.

\section{The success of service organizations}

A service organization: A group that contains individuals who are responsible for performing a range of skills and functions related to the process of product flow from producers to customers in the target markets (Al-Zmour, 2006: 22).

The success of the organizations is nothing but an administrative problem resulting from the difference of researchers in their awareness of this concept and the extent of their personal interest in organizational changes without the other, as a result of their intellectual and personal bias to the values of others. (Al-Rikabi, 1999: 133) 
Thus, the service organization depends on the distribution of the commodity, as the distribution among the organizations is a group of activities that start by entering the commodity in its use form to the commercial store, and until the consumer receives it, and thus the service organizations are disciplined in terms of time and how to manage it fully. (211, Proctor )

Thus, the vision of organizational success becomes clear as the organization's ability to survive, adapt, and grow in light of the goals it seeks to achieve, which leads to the effective strategic alignment that these organizations aim to achieve success (Dell \& Kramer, 2003; 1)

Organizational performance

The concept of performance comes as the achievement of organizational goals by using resources efficiently and effectively, and so the outputs are what the system seeks to achieve, that is, it works to link the aspects of activity and the goals that these activities seek to achieve within the organization. (Speech, 2001: 11).

Creative leadership

Leadership is nothing more than creating a vision that is successful, concerned with formulating the goal by proving strategies that achieve the spirit of cooperation, since the leader who prioritizes the formulation of successful future visions must have a spirit of creativity and work to take things with legitimate interests that satisfy all parties, while He may be able to succeed after arriving at a strategy through which his ideas are invigorated, by participating in setting the right and right goals. (Ali Lounis, Dalal Jaghyoub, 2013: 23)

So leadership is the process that is influential by a leader in his subordinates to persuade them and urge them to actively contribute to their efforts to undertake collaborative activity. (Naeem, 2005: 44)

While the leadership has a leader who must be creative in mastering his work for the success of the organization, through the method offered by the leader in his work and who possesses these capabilities and experiences to foresee the future, forecast future needs, and work diligently to present challenges for preparation in advance and tasks that are in the priorities of his tasks, As the leader works with every activity and activity to achieve the goals with a specific time and evaluate his work in a timely manner (Noah, Abdel Aziz, 2011: 87)

\section{Practical}

For the purpose of testing the research hypotheses, a survey form was prepared for the opinions of employees in the directorate of Dhi-Qar Municipalities who have a direct contact with the reality of accounting and supervisory work in a manner that achieves the objective of the form, as the results of the graphical analysis of the research sample were as follows:

\begin{tabular}{|c|c|c|c|}
\hline \multicolumn{4}{|c|}{ Table (1) The total number of the research sample } \\
\hline details & $\begin{array}{c}\text { The total number of distributed } \\
\text { forms }\end{array}$ & Right & Excluded \\
\hline $\begin{array}{c}\text { the } \\
\text { number }\end{array}$ & 62 & 47 & 15 \\
\hline percentage & $\% 100$ & $\% 76$ & $\% 24$ \\
\hline
\end{tabular}

Table (2) Reliability Statistics

\begin{tabular}{|c|c|}
\hline \multicolumn{2}{|c|}{ Table (2) Reliability Statistics } \\
\hline Cronbach's Alpha & N of Items \\
\hline .775 & 12 \\
\hline
\end{tabular}




\begin{tabular}{|c|c|c|c|c|c|c|}
\hline \multicolumn{7}{|c|}{ Table (3)Case Processing Summary } \\
\hline & \multicolumn{2}{|c|}{ Cases } \\
\cline { 2 - 7 } & \multicolumn{2}{|c|}{ Included } & \multicolumn{2}{|c|}{ Excluded } & \multicolumn{2}{|c|}{ Total } \\
\cline { 2 - 7 } & N & Percent & N & Percent & N & Percent \\
\hline $\begin{array}{c}\text { Time management } \\
\text { Achieve goals }\end{array}$ & 47 & $100.0 \%$ & 0 & $0.0 \%$ & 47 & $100.0 \%$ \\
\hline
\end{tabular}

\begin{tabular}{|c|c|c|c|}
\hline \multicolumn{4}{|c|}{ Table (4)Correlations } \\
\hline & & $\begin{array}{c}\text { Time } \\
\text { management }\end{array}$ & Achieve goals \\
\hline \multirow{3}{*}{ Time management } & Pearson Correlation & 1 & $.706^{* *}$ \\
\hline & Sig. (2-tailed) & & .000 \\
\hline & $\mathbf{N}$ & 47 & 47 \\
\hline \multirow{3}{*}{ Achieve goals } & Pearson Correlation & $.706^{* *}$ & 1 \\
\hline & Sig. (2-tailed) & .000 & \\
\hline & $\mathbf{N}$ & 47 & 47 \\
\hline
\end{tabular}

The cognitive scale of the research sample: The cognitive scale: is a transformation of the weighted averages in the Likart scale by adding the product of the sample choices multiplied by the weighted weight divided by the number of the sample, which shows the extent of knowledge that the research sample has for the paragraph that was answered and the more the scale exceeds 2 whenever The knowledge of the sample increased.

\begin{tabular}{|c|l|c|c|c|}
\hline \multicolumn{2}{|l|}{ Paragraph : Time management } & MEAN & STD. & scale \\
\hline 1 & I am facing some difficulties in lack of time & 2.47 & .667 & agree \\
\hline 2 & I can organize time to do all the work & 2.4 & .712 & agree \\
\hline 3 & $\begin{array}{l}\text { I always distribute works according to the estimated time } \\
\text { management }\end{array}$ & 2.66 & .522 & agree \\
\hline 4 & It's easy to control my time & 2.79 & .414 & agree \\
\hline 5 & $\begin{array}{l}\text { Take the time to complete the necessary and necessary } \\
\text { actions first and then unnecessary. }\end{array}$ & 2.49 & .655 & agree \\
\hline 6 & $\begin{array}{l}\text { I rarely encounter obstacles that take a lot of time to do } \\
\text { my job. }\end{array}$ & 2.89 & .375 & agree \\
\hline
\end{tabular}

\begin{tabular}{|c|c|c|c|c|}
\hline \multicolumn{2}{|r|}{ Paragraph : Achieve goals } & MEAN & STD. & scale \\
\hline 1 & I always set goals for achieving it & 2.96 & .204 & agree \\
\hline 2 & I lay out all possibilities for achieving business goals & 2.91 & .351 & agree \\
\hline 3 & I always have time to achieve my goals & 3 & $\mathbf{0 . 0}$ & agree \\
\hline 4 & $\begin{array}{l}\text { I lay out the methods and methods that lead me to achieve } \\
\text { my goals }\end{array}$ & 2.55 & .775 & agree \\
\hline 5 & Share subordinates with me to consult on achieving goals & 2.912 & .282 & agree \\
\hline 6 & I can take the time to manage and reach my goals. & 2.83 & .433 & agree \\
\hline
\end{tabular}




\begin{tabular}{|c|c|c|c|c|c|}
\hline \multicolumn{6}{|c|}{ Table (5) ANOVA } \\
\hline & Sum of Squares & df & Mean Square & F & Sig. \\
\hline Between Groups & 2.891 & 7 & .413 & 9.355 & .000 \\
Within Groups & 1.722 & 39 & .044 & & \\
Total & 4.612 & 46 & & & \\
\hline
\end{tabular}

\section{Conclusions and recommendations}

After reviewing the theoretical side and statistical analysis of the research sample in the municipal departments of Dhi Qar, the researcher reached the following conclusions:

1. That time management directly affects the achievement of the goals of the organization (municipal service departments)

2. The strategy for organizing time and managing it will facilitate the task of management in achieving the goals and as a result reduce public expenditures and increase productivity in the services provided.

3. The correct time management will lead to administrative decisions at the right time and without affecting the quality of services provided to others.

In light of the previous findings, the researcher recommends a set of recommendations according to the following:

1. Developing and improving time management systems in municipal departments to meet the needs of departments and departments at all levels.

2. The decision-makers should consider the importance of time management as a tool to help them in making decisions to overcome the difficulties and problems facing them.

3. The clarity of the procedures and powers granted to administrative levels in decisionmaking and the involvement of employees in organizing their job time leads to reducing waste and achieving the maximum productive benefit.

\section{References}

[1] Abdul-Aziz Noah, the reality of school principals in Riyadh using the goal-oriented management style, Journal of Education and Psychology, Saudi Society for Educational and Psychological Sciences, King Saud University - Riyadh, No. 37, 2011.

[2] Al-Zmour, Hani Hamid, Department of Distribution Channels, Wael House for Publishing and Distribution, 1st edition, Amman - Jordan, 2006.

[3] Bashir Al-Alaq, Fundamentals of Time Management, Al-Yazurdi Scientific Publishing and Distribution House, 1st edition, Amman - Jordan, 2009

[4] Dell, David \& Kramer, Robert (2003), forging Strategic Business Alignment ", The Conference board.

[5] Jaghboub Dalal, The Concept of Creative Time Management at King Bani Nabi, PhD thesis in Educational Administrative Sciences, University of Mohamed Lamine Dabbaghine, Setif, Algeria, 2016.

[6] Khattab, Aida, Strategic Management: An Introduction to the Twenty-first Century, 4th Edition, Academic Library, Arab Thought House, Cairo, Egypt, 2001.

[7] Muhammad Hassanein Al-Ajmi, Modern Trends in Administrative Leadership and Human Development, 2nd floor, Al Masirah House for Publishing and Distribution, Jordan, 2010.

[8] Naeem Ibrahim Al-Thaher, Effective Time Management - World of Books for Publishing and Distribution, Jordan - Amman, 2013. 
[9] Naseer Naeem, Administrative Leadership, Arab Organization for Administrative Sciences, 1st edition, Amman - Jordan, 2005.

[10] Proctor T, Marketing management integration theory and practice, international Thomason, press, London, p 211.

[11] Raad Hasan Al-Sarn, The Art and Science of Time Management, Dar Al-Reda for Publishing and Distribution, 2000.

[12] Raad Hasan Al-Sarn, Time Management, Damascus University Publications, Syria, 2018.

[13] www.conferenceboard.org. 